\title{
Ghosts in the Shell: On South Africa, the USA and Japan
}

\section{Daniel McKay}

Contrary to expectation, China did not prove warlike. She had no Napoleonic dream, and was content to devote herself to the arts of peace. After a time of disquiet, the idea was accepted that China was to be feared, not in war, but in commerce.

Jack London, “The Unparalleled Invasion” $(1910)^{1}$

I have in the course of my life ... [had] contact with many different cultures and races, and I don't think that cultures really clash, that if one understands another culture you're enriched by it. They're all sources of enrichment. And all these differences we think which divide black and white, yellow and white, Japanese from Europeans, Chinese from Americans, all these differences-if we understand what they try to give life-would be sources of enrichment to the community to come. It's just all in the understanding.

Laurens van der Post, Interview (1992)

Postcolonial scholarship that addresses the representation of China-and, more broadly still, East Asian national cultures-in Anglophone literature routinely ranks Jack London's “The Unparalleled Invasion” (1910) as among the most Sinophobic source materials to date. London's story belongs to the tail-end of what Takayuki Tatsumi has termed the "future war fiction" of the nineteenth century, a body of writing that played upon the race fears some Americans entertained in respect of particular ethnic-national groups. ${ }^{3}$ Such texts usually drew upon a stock of preconceived notions - in this case, that of the thrifty, overindustrious Chinese migrant-in order to construct an imagined scenario of war as the fulcrum in which white America falls or triumphs. London's contribution is perhaps especially noteworthy because the moment of conflagration is anticipated

Email: dem52@uclive.ac.nz

${ }^{1}$ London, "The Unparalleled Invasion," 310.

${ }^{2}$ van der Post interview by Sandra Herrington, SATV Channel.

${ }^{3}$ Tatsumi, Full Metal Apache, 63-70. 
as taking place some six decades in the future (that is, following publication of the story), which is uncannily close to the real-life market reforms that have seen mainland China grow into the economic powerhouse as it is today. But London's predictions were more wrong the right, particularly his scenario of a global alliance of wealthy nations annihilating the Chinese and repopulating the mainland from 1982 onward. As scholars of the Asia-Pacific now know, the 1980s were a time in which American scaremongering ushered in a wave of dystopian cultural productions that fixated upon Japan's economic ambitions, not China's. The second epigraph to this article contains a passing nod to that polemic, though its language is not cast from a dystopian mold. On the contrary, in the interview from which it is drawn the South African-born British-resident author Laurens van der Post takes up an antithetical position to London's, imagining amity-rather than conflict-amongst national cultures and drawing upon his longstanding fascination with the San or "Bushman" as a model society. Ultimately, van der Post's view of the San may have been as sentimental as London's view of the Chinese was fearful, but his tacit acknowledgment of longstanding tensions between Japanese or Chinese (on the one hand) and Europeans or Americans (on the other) is worth underscoring in any case because whereas postcolonial readings make much of the polarities London reinforced, there has been less attention given to artists and intellectuals who wrote against or otherwise ignored those resurrected polarities.

In what follows, I offer a synopsis of the anti-Japanese (Japanophobic) trend in American literature as it took place from the late 1970s to the early 1990s and contrast that cultural phenomenon with its absence in the writings of van der Post, focusing particularly upon his autobiography Yet Being Someone Other (1982). Although World War II saw the author imprisoned by the Japanese on Java, a subject he does not neglect in the autobiography, the lasting animosities that tended to manifest in surviving POWs are nowhere present in his work. This in itself would be remarkable on any occasion, but is all the more so given the Japanophobic discourses that were emanating from across the Atlantic-discourses that became or were already interpellated by other Anglophone communities, particularly (though not always) those that included World War II veterans. In speaking of absence, whether at a national or an individual level, one ought not to assume that yesterday's fears no longer hold sway over the imagination when, in point of fact, it may be the geopolitical stimuli alone (military build-up, economic tensions, territorial disputes, etc.) that disappear and not the fears that precede and grow upon them. A "false dawn" of this sort goes some way toward covering over the antagonism of formerly belligerent peoples but demands little in the way of selfcriticism and reconciliation from either party, especially given that the successive relationship may be founded upon a pressing set of geopolitical exigencies that demand a swift response. ${ }^{4}$ The aftermath of the Asia-Pacific War serves to

\footnotetext{
${ }^{4}$ Kohei Hanasaki summarizes this scenario in respect to Japan's postwar history: "In the Japanese case, the decolonization process as such, as distinguished from demilitarization, had a relatively small impact on the domestic course of affairs. To put it in another way, decolonization was reduced to demilitarization." See Hanasaki, "Decolonization and the Assumption of War Responsibility," 72.
} 
illustrate this point. Once hostilities between the USA and the Empire of Japan had ceased and the Occupation was in place, American strategists reformulated Japan's strategic "position" away from that of a belligerent power to a capitalist "bulwark" against Communism, thereby consigning the propaganda of the war years to an immediate (but temporary) irrelevance. ${ }^{5}$ At a purely practical level, this resulted in the reindustrialization of the Japanese economy so as to provide goods and manufactured products to American personnel stationed on the continent, but getting the American public used to the idea of Japan as ally meant that ideas and cultural understandings also had to be "produced" and made available in turn. One can perceive the role of literary writers keeping pace with these changes, James A. Michener's Sayonara (1954) and James Salter's The Hunters (1956) both offering pertinent examples of what took place. These novels were written as expositions on the lives of fighter pilots during the Korean War, but they also betray a deep interest in how American airmen fared while on leave in Japan. Recollecting this time, Salter's main character reveals that, having imbibed the hospitality of Japan, he no longer gives much thought to returning to the USA:

The States were far away, impossible even to think of. Only to be in Tokyo once more, only that, down the wide avenues in the warm evening, beside the river, through the park. There was no pleasure in the world to equal that, as it passed through his mind like bursts of music. ${ }^{6}$

For Korean War servicemen, Japan became what Australasia had been during the Pacific War: a surrogate for home and, in rarer cases, better than home. These demographic and literary developments did not render World War II a redundant topic, but the propaganda images of that conflict were out of step with contemporary geopolitical realities and likewise did not reflect the experiences of those Americans who were going to Asia in unprecedented numbers during the postwar years. ${ }^{7}$

\section{JAPANophobia IN the United States}

From the late 1970s to around 1994, the results of Japan's reindustrialization-namely, an increasingly competitive business sector-provoked attention from American news media, fiction writing, travelogues, and sundry other avenues of address, the content of which could be openly admiring but also, on occasion, rather overawed or even fearful. Since the time of the Meiji Restoration,

\footnotetext{
${ }^{5}$ Shibusawa, America's Geisha Ally, 3.

${ }^{6}$ Salter, The Hunters, 184.

${ }^{7}$ Writing of this trend, Christina Klein states that "Part of the reason why Americans were especially interested in Asia after World War II was that the Cold War made Asia important to the United States in ways that it had not been before. [...] Hundreds of thousands of Americans flowed into Asia during the 1940s and 1950s as soldiers, diplomats, foreign aid workers, missionaries, technicians, professors, students, businesspeople, and tourists. Never before had American influence reached so far and so wide into Asia and the Pacific." See Klein, Cold War Orientalism, 4-5.
} 
Anglophone writers and intellectuals had positioned "the West" as offering a model for Japan's economic development, and in 1975 a meeting of the newly formed G-6 (soon to be G-7) organization appeared to cement this identification of "the West" as "developed," even though one member, Japan, was located in East Asia. ${ }^{8}$ As Martin W. Lewis and Kären Wigen observed in their critique of metageography, "The implicit contention is that Japan has been Westernized simply by becoming rich and powerful." ${ }^{\prime 9}$ This perspective was to undergo a series of seismic shocks, particularly after the realization that Japan, though certainly developed, was not following Western systems of industrial organization. By the end of the 1980s, public intellectuals were wryly commenting how economic development served more to problematize Japan's "Western" identity than confirm it:

The West resents what it sees as the inscrutable, the remote and the ambiguous nature of Japanese culture. What disturbs the West most of all is that this alien culture has now become "Number One"; Japan has become the model of economic and technological progress. Japan is now more modern, and maybe even more postmodern, than the West. ${ }^{10}$

These anxieties played out in obtuse and obvious ways in the corporate thriller genre, of which Michael Crichton's Rising Sun (1992) is only the most well known. ${ }^{11}$ Steven Schlossstein's Kensei (1984), a forerunner, does just as well when it comes to revealing the signature features of this literary form, namely an impending sense of national decline in the USA counterpoised against a quixotically efficient form of socioeconomic and industrial organization in Japan; a didactic narrative style that purports to summarize the distinguishing features of Japan, the Japanese, and their principal institutions; and an 11th-hour stay of execution for the sovereignty or safety of the USA. Schlossstein goes one stage further though, envisaging a possible military confrontation after a stolen American computer chip supplies the missing component to a concealed Japanese rocket arsenal. $^{12}$ The scenario is reminiscent of the 1967 film version of Ian Fleming's novel You Only Live Twice (1964), which likewise imagined a concealed rocket base in Japan, although the Japanese of Fleming's world are still the rehabilitated Cold War allies of Michener and Salter's era.

Not coincidentally, this was also a period that saw veterans of the Asia-Pacific War publishing their memoirs, among which William Manchester's Goodbye, Darkness (1980) and Eugene Sledge's With the Old Breed (1981) are especially noteworthy. The level of detail revealed to-or inflicted upon-the reader in all

\footnotetext{
${ }^{8}$ Minear, "Orientalism and the Study of Japan."

${ }^{9}$ Lewis and Wigen, The Myth of Continents, 51-2.

${ }^{10}$ Robins and Morley, "Japan Panic," 32.

${ }^{11}$ For a summary of how Rising Sun was received in the United States, see McKevitt, "Consuming Japan," $132-5$.

${ }^{12}$ Schlossstein, Kensei, 257-8.
} 
matters, but especially those of field hygiene (its challenges), frontline medical aid (its desperate bravery), and identification with the enemy (its lethal inadvisability), gave these writings a haunting authenticity that garnered immediate attention in military and civilian circles alike. ${ }^{13}$ But Manchester's narrative was not purely retrospective. Interspersed among his recollections of life in the US Marine Corps were short commentaries on what he found upon revisiting the battlefield sites prior to writing the memoir. One receives the distinct impression, reading these, that Manchester was not always pleased by the behavior of those he encountered. Here, for example, is his notation of how Japanese tourists were conducting themselves on Guam:

With the round-trip fare from Honshu only $\$ 130$, three-fourths of arriving passengers at the airport are Japanese. They have no interest in war relics; they seem unaware that there was a war here. Wearing ten-gallon hats, they feast on thick sirloin steaks in Agana's nightclubs and enthusiastically applaud go-go girls. ${ }^{14}$

To Manchester's way of thinking, the Japanese on Guam are too plentiful, too ignorant, and too hedonistic-in short, too undeserving of the host culture and the battlefield sites that, by rights, ought to make anyone contemplative. ${ }^{15}$ The nightclub life to which he takes exception may or may not be appropriate on its own terms, but implicit in his critique is a sense of outrage that the Japanese have been able to use their tourist dollars, sustained, as everyone knew, by a healthy trade surplus with the USA, to purchase for themselves a lifestyle that cushions them from the "unpleasantness" of the Asia-Pacific War. To a reader of the 1980s, the equation between a trade surplus and a purposeful ignorance of history at the individual level would have come through in the prior passage. It was very simple: the higher the profit margins of those Japanese companies operating in the USA, the wealthier individual Japanese "salarymen" were becoming; and the wealthier they became, the more opportunities they could afford in which to thumb their noses at, or otherwise ignore, the pilgrimage-cum-heritage sites of the war (which Manchester's memoir, without a shred of irony, brought to the attention of those

\footnotetext{
${ }^{13}$ Reviewing With the Old Breed, a retired US Marine Corps officer acknowledged the work's gritty realism: "Perhaps better than any other contemporary author, Sledge shows combat to be not only a baleful compound of dirt, fright, violence, and stench, but also a brutally fatiguing form of manual labor which can reduce superbly conditioned young men to complete exhaustion in a matter of hours." See Bevilacqua, "With the Old Breed," 56.

${ }^{14}$ Manchester, Goodbye, Darkness, 282.

${ }^{15}$ It is worth noting that Manchester's pilgrimage around battlefield sites and combat zones was, by the time of writing, a literary tradition as well as a tourist practice. Thirty years previously, James A. Michener had embarked on a similar pilgrimage, sans Japanese tourists, and wrote of Guadalcanal with deep sympathy for the combatants on both sides: "I tried to imagine what it must have been like to the men who hated it, and I was sorry that anyone, American or Jap, had ever been forced to live under such conditions. I understood why even rugged Japanese troops had collapsed and died in that stifling mid-day heat, how they starved in this impersonal sea of greenness. Add constant malaria for quaking fevers, and this was forbidding terrain. Twigs crackled, and I needed no flight of fancy to know how increased the terror would have been with Jap snipers lashed in the crotches of the silent trees." See Michener, "Guadalcanal," 129-30.
} 
American readers whose own memories, for whatever reasons, might have been a bit unreliable when it came to the various island campaigns).

Not every travelog published during this period waxed so antagonistic. In the midst of these polemics Yet Being Someone Other quietly appeared in 1982, the same year in which Roland Barthes' Empire of Signs was released in a posthumous English translation. Nor did the coincidences end there. A number of other events would serve to punctuate that year more gruesomely, discussed later in this article in more detail. For now, though, Barthes' third-person account of his own trip to Japan is worth acknowledging:

The author has never ... photographed Japan. Rather, he has done the opposite: Japan has starred him with any number of "flashes"; or, better still, Japan has afforded him a situation of writing. This situation is the very one in which a certain disturbance of the person occurs, a subversion of earlier readings, a shock of meaning lacerated, extenuated to the point of its irreplaceable void, without the object's ever ceasing to be significant, desirable. ${ }^{16}$

As van der Post's friend William Plomer noted half a century before, Japan is a country that titillates the foreigner's urge to strike a rhetorical pose or, in Plomer's own words, "Every outsider who sets foot in Japan at once, as if by some chemical reaction, produces a book on that subject." 17 Barthes appears to be no exception to the rule, though his description of a welcome disturbance of selfhood rather than an affirmation of stereotypes (his preference is to interrogate them) not only bucked a long literary trend but provided a sound ideal for subsequent writers, as Darko Suvin acknowledged in his combined travel account and reading of Barthes:

Japan is in terms of bodily impressions-jet lag, unreadability of script and behaviour, different evaluation of gender and age, etc.-indeed halfway to the Moon for a European. It is the nearest approximation to a science-fictional planet we can actually live in, with deeply strange yet tantalizingly permeable relationships forcing us to constant decipherment on pain of anomie. ${ }^{18}$

Empire of Signs really is a series of snapshots taken at double exposure; of impressions of Japan seen only in the distant background and of Barthes himself reading his impressions in the foreground. The interior workings of pachinko machines, the sliced and diced eel, and the nameless Japanese streets, all flitter before his eye in a way that one could describe as aimless, provided that one understands that "taking aim" is not always a good thing.

But 1982 saw a more visceral signifier of the degree to which Americans felt uneasy with the rise of Japan. In the news media, the changing economic climate was "explained" to Americans through the discourse of the Pacific Rim, which

\footnotetext{
${ }^{16}$ Barthes, Empire of Signs, 4.

${ }^{17}$ Plomer, Paper Houses, ix.

${ }^{18}$ Suvin, "The Soul and the Sense," 501.
} 
envisaged a baton being passed from the Atlantic to the Pacific. ${ }^{19}$ The message seemed to be that one could adjust, or that one could protest, though it was not clear how either was to take place, and, in June of that year, two men, embittered at mass job redundancies in Detroit, took matters into their own hands by beating a Chinese American to death after apparently mistaking him for Japanese. ${ }^{20}$ The death of Vincent Chin grimly correlated with the grievances that had been engendered by the increased market share of the Japanese car industry (and the "restructuring" of Detroit's own industries), and also made clear that rising prosperity among Chinese and Japanese Americans did not necessarily lead to greater levels of acceptance in larger society; too often they were seen as "foreign."21

In all probability, this "foreignness" attributed to ethnic East Asians in Western societies likewise held true in South Africa, though for that country 1982 marked a turning point of a different sort. Since the seventeenth century, the overseas trading relationship of the Cape had been markedly oriented toward Europe, developing without any contact with the indigenous Indian Ocean shipping networks, whether African or Asian. ${ }^{22}$ But in 1982, Japan became South Africa's largest export market for the first time, a situation born of necessity as much as choice, admittedly, but insofar as Japan had not forced the trade relationship on South Africa, there was no animosity. ${ }^{23}$ Nor had Japan bested any European or American corporation in lobbying, contracting, or manufacturing-rather, the former were gradually disinvesting as part of international sanctions brought to bear on the apartheid regime (Japan would achieve most favored nation status in 1985). In light of these arrangements, Japanophobia never took hold in South African society and politics, the upshot of which, in cultural terms, meant that even as South Africa was frozen out of political and economic bodies, it was cocooned from the resurrected tropes of the Asia-Pacific War currently circulating in Australia, New Zealand, the USA, and elsewhere. Strange as it may seem, therefore, one needs to imagine the movement for anti-apartheid sanctions as unwittingly erecting a sort of cordon sanitaire that allowed van der Post to meditate on what Japan and South Africa had meant to one another even as Anglophone cultural productions elsewhere were drawing hasty conclusions.

\section{Yet Being Someone Other}

Having thus outlined the context in which van der Post published Yet Being Someone Other, it should not be assumed that the work is in any way a rebuttal of the corporate thriller, the combat memoir, or any other genre on which Japano-

\footnotetext{
${ }^{19}$ Cumings, "Rimspeak," 55-6.

${ }^{20}$ Though virtually unknown to South Africans, the death of Vincent Chin is frequently referenced in Asian American scholarship. For a study of how mass redundancies in the auto industries of Detroit led to spiraling discontentment among some of the unemployed, see Frank, "Demons in the Parking Lot."

${ }^{21}$ Tuan, Forever Foreigners or Honorary Whites?, 41-3.

${ }^{22}$ Ward, "Tavern of the Seas?," 144.

${ }^{23}$ Osada, Sanctions and Honorary Whites, 69.
} 
phobia found purchase. The main subject of this autobiography was the same as it had always been in most of the author's prior publications, namely van der Post himself. Indeed, quite why the 1980s should have occasioned his interest may be unclear until one recalls the author's fascination with the San or "Bushman" people. The anthropologist Edwin N. Wilmsen has investigated the matter of how, why, and when van der Post became an acknowledged authority on the bushman and pays particular attention to the context of the Cold War as a backdrop for van der Post's writings. The threat of Communist encroachment into public and political life and the even more imminent sense of nuclear annihilation, all of which came to a head in the 1950s-1960s, left Western Europeans and Americans struggling to retain a sense of cultural equilibrium and social continuity. ${ }^{24}$ Like many of his contemporaries, van der Post "responded by inventing a primitive (in both senses of first and fundamental) past world as a foil to a seemingly apocalyptic present which confronted Euro-Americans, individually and collectively, with an existential crisis." ${ }^{25}$ Redemption of a quasi-spiritual sort was a core value imbued within the resultant corpus of material, but insofar as van der Post succeeded in his role as a redeemer, he did so only for as long as apocalyptic visions held their grip on the public consciousness. By the 1980s, this vision had begun to give way before the specter of a new threat, more quotidian but of an older lineage. In this decade, the rise of Japanese capital, with its attendant technologies, the car, the Walkman, the semiconductor chip, the advanced computer, etc., challenged the socio-cultural confidence of Americans, because these products, and the corporations responsible for their manufacture, appeared to have surpassed the USA not only at the research and production level, but in their role as signs of a developed society. ${ }^{26}$ The 1980 s, in other words, were a period that ushered in a new set of existential anxieties and might have provided van der Post with the chance to author another "redeeming" agent to stand alongside the bushman of the 1950s-1960s period. However, this was not to be. His previous publications, The Seed and the Sower (1963) and Night of the New Moon (1971), had already provided graphic images of life and death in a Japanese-run POW camp, which meant that the topic of how to "view" or "approach" the Japanese was no longer fresh by the time van der Post came to write Yet Being Someone Other. Thus, the Japanese, as they came across in his writing, could not be "injected" into the public consciousness as redeeming agents like the bushman had been before them, for they constituted an old topic and, quite apart from anything else, their economic muscle had already served to paint them as perpetrators in the public eye. The best

\footnotetext{
${ }^{24}$ Goodheart's reading of the literature of this period corroborates the sense of anomie that held forth in society. As Goodheart tells it, "There are good historical reasons for this nihilism: the atomic bomb, the incredible devastations of contemporary wars and concentration camps. Recent German literature, in particular, has taught us that the natural impulse toward immediate indignation or protest yields to a kind of resignation in the feeling that the enormities of contemporary life are not subject to the human will - that they are too deep in human character to be exorcised by conventional moral responses." See Goodheart, The Cult of the Ego, 7 .

${ }^{25}$ Wilmsen, "Primal Anxiety, Sanctified Landscapes," 146.

${ }^{26}$ For a summary of the trade anxieties in the United States, see Noble, “Takeover or Makeover?," 129-30.
} 
option available to van der Post was to use his own story as a way to deepen people's understanding of the historical ironies and junctures backed up behind the rise of Japan as an economic power.

The war years contained some lessons and parallels with present-day current affairs, as American writers like Manchester knew well, but van der Post placed just as much emphasis on the interwar period and, in particular, the time he spent as a passenger on board a Japanese vessel in 1926. Of this experience, novelist and shipmate William Plomer would later write that the ship's skipper, Captain Mori, "seemed to be bearing us off to his far country very much as in the days of Captain Cook exploring navigators used sometimes to carry home for exhibition in Europe natives of the Pacific islands." ${ }^{27}$ Plomer's analogy was not misplaced. In fact, the practice of transporting "representative" natives carried over into the first recorded contacts between Japanese and Americans in the early nineteenth-century, well before Commodore Perry opened up the country in 1853. In 1832, for example, three Japanese sailors, marooned off the West coast of Canada, were taken as slaves by Clayoquot Indians, successfully "purchased" by white Canadians, provided an English education, and subsequently transported to Britain before being taken round the Cape of Good Hope on their way back to Japan. ${ }^{28}$ Nothing is known of how they were received in South Africa at the time, or whether South Africans even took note of their passage. Certainly, the British Government was not impressed by the plan of the Hudson Bay Company to make use of these sailors in opening up Japan to foreign trade. What we do know, in an interesting twist to the tale, is that quite a few Americans had become convinced that the Japanese were descendants of Native Americans, owing to the similarity in appearance between the two peoples. ${ }^{29}$ Then as now, sailors and governments were often mistaken in their anthropology and, roughly one hundred years later, the potential for misunderstanding had not diminished, though different questions were being asked and it was now Japan's turn to pick up a few "specimens" here and there. ${ }^{30}$

If the voyage of 1926 provided van der Post with a body of experience on which to draw, it is perhaps unfortunate, if only from an historical point of view, that the author chose not to distinguish between the inexperience of a younger self and the worldliness he possessed at the time of writing, for then one might have a clearer understanding of the extent to which this trip impacted upon him. However, if van der Post makes no real distinction in the political values or moral tone that separates "what I knew even then" from "what has become apparent," the ideals to which he subscribes at the time of writing come through all the more strongly. A

\footnotetext{
${ }^{27}$ Plomer, The Autobiography of William Plomer, 180.

${ }^{28}$ Kamei, “The Harbingers of Japanese-American Cultural Relations,” 21-3.

${ }^{29} \mathrm{Ibid}$.

${ }^{30} \mathrm{~A}$ curious point of historical coincidence took place during the same year in which van der Post and Plomer went to Japan. It was then that a new era of American tourism to South Africa was set in motion with the voyage of the "Orca" from New York City. Had events conspired to bring the two South Africans to the United States instead of Japan, their life histories and perspectives would surely have taken an altogether different turn. See Woolf, “A Grand Tour,” 111-2.
} 
case in point is van der Post's meditation on the susceptibility of South African society to European ideologies common at the turn-of-the-century and the ways in which these fed into prevalent anxieties specific to the South African social context:

\begin{abstract}
in a country like my own, so firmly in the grip of racial and colour prejudices of all kinds, warnings like those of the Kaiser about the "yellow peril" were still echoing from the walls of our little world which was so much closer to the heart of the matter. They rendered more plausible the protest of commerce and industry which saw another form of danger from the new Japan. They held that Japanese businessmen and manufacturers were not to be trusted; that they stole their industrial designs from the West, pointing to the common charge that Japanese pencils, which were apparently driving their own out of the market, had lead only in the ends and were hollow in-between. It did not seem to strike anyone that all this could have been honest errors due to the haste in making up the "leeway of the centuries." 31
\end{abstract}

Does van der Post attribute this relative thinking to his viewpoint in 1926 or in 1982? It remains unclear, and yet the potential charge that he has conflated his two selves is much less significant than the parallels between the "yellow peril" invective here cited and the Japanophobia of the 1980s. Accusations of industrial espionage were a feature of both periods, though the 1980s focused on corporate malpractice both as a worthwhile topic in its own right and as an allegory or harbinger of military intervention. As van der Post terms it, the "heart of the matter" would appear to be racial tension, something he had previously observed as being so prevalent within South African society that moments of great injustice in that country, and that which took place during his time as a prisoner of the Japanese, tended to stand in for one another in his memory. ${ }^{32}$ The racial inequality of his homeland was something van der Post simultaneously deplored and found useful as a point of reference that made him especially well qualified to comment on similar situations elsewhere. In point of fact, according to his account, the course of events that saw him embark upon a voyage to Japan was initiated after he overheard a café proprietress evicting two Japanese from her whites-only establishment. ${ }^{33}$

The ways in which the 1926 voyage to Japan stimulated comparisons with the discourses in circulation at the time of publication come across most strongly during the author's recollection of his visit to a cotton factory:

We arrived just in time to see some thousands of young girls, employed in the factory, the managerial staff and directors of the company, preparing to say goodbye to the old looms discarded for the modern types which Britain ironically could supply but still thought too expensive for a declining Lancashire. The girls were neatly dressed, well-nourished and looked far too happy for the slave-labour their competitors in Britain and Europe accused them of being. They welcomed us with smiles, giggles and shy delight, to become serious only when the moment of farewell to their old machines arrived. They bowed deeply to their looms as though they were people; thanked them for their loyal service

\footnotetext{
${ }^{31}$ van der Post, Yet Being Someone Other, 112.

${ }^{32}$ van der Post, Jung and the Story of Our Time, 28.

${ }^{33}$ van der Post, Yet Being Someone Other, 108.
} 
and wished them well in their future industrial reincarnations. The mystique of commerce and religious fervour that went into industry of which I had a hint in Tokyo was made manifest in a manner there, formidable with implications for the future which are only now becoming apparent to the world. ${ }^{34}$

Van der Post's interest in the female rather than the (implicitly male) managerial staff, as well as his slight derision at their formalities and rituals, serves to render the Japanese in buffoonish terms, but to read this passage as a piece of colonialist discourse is to go only skin deep, for the focus does not look back upon the cotton looms of 1926 so much as forward to the hi-tech economy of 1982-or, rather, the first is seen to presage the second. ${ }^{35}$ The shifting time frames are also matched by a change in tone, which sees casual mockery giving way to a sober premonition, suggesting, in turn, that mockery is not, in fact, the wisest nor a well-observed response, and that van der Post is one step ahead of his readers in outlook as well as experience. In short, the deployment of a literary typology that feminizes or infantilizes Japanese society constitutes a ruse that disguises a healthy respect for Japan's industrial achievements. Far from being misrepresentative, therefore, the passage is concerned with misrepresentation as a topic and an ongoing problem (as the author points out, the curious portrayal of the Japanese workers as slaves, perhaps akin to the term "economic animal," used to refer to Japanese businessmen in the 1970s and 1980s, is a poor deflection from the self-inflicted weaknesses of the Lancashire cotton industry). For the reader of 1982, this is a carefully constructed déjà vu moment in which stereotypes get challenged or, to take a leaf out of Roland Barthes' book, earlier readings become subverted. But van der Post does not tell us that the rhetoric of the 1980s is erroneous. No comparisons take place. Rather, it is left to the reader to supply the bases and realize that deploying loaded terminology against one's competitors is inherently suspect, as was the silliness behind the assumption that people who import machinery for improved production will not try their hand at producing the machines themselves.

Elsewhere in Yet Being Someone Other, the author's historical relativism is certainly enabled by the specifics of South Africa's economic relationship with Japan during the 1980s, but not driven by it. Most of van der Post's observations take the voyage of 1926 as a worthwhile-indeed, the primary-story in its own right. Here it is worth remembering, if only in passing, that these were the years in which British writers and gentry embarked on a term (sometimes lasting a

\footnotetext{
${ }^{34}$ Ibid., 253.

${ }^{35}$ Japan's position as a manufacturer of pencils in the 1920s anticipated its position in the postwar decades as the world's largest exporter of tin toys, an occupation that observers initially derided as 'tinkerdom' but which laid the foundations for a world-renowned industry by the end of the century. See Tanner, "Toy Robots in America."
} 
lifetime) of voluntary exile from their homeland, disgusted by the war, the weather, and the perceived Philistinism of society, and liberated by the easing of travel restrictions that had hitherto confined them to the home country. ${ }^{36}$ The young van der Post appears to have got caught up in the tailwind of this phenomenon and acquired his own desperate need to depart South Africa. Only the aforementioned commentary on Japan's industrialization can, therefore, be read as purposely relevant to the 1980s, whereas moments elsewhere need to be approached more cautiously. There are, for example, the shipboard encounters that took place on the Canada Maru that served to accelerate the pace of young van der Post's acculturation once he embarked on his journey. As a book reviewer acknowledged, the "interior voyage on the Canada Maru was infinitely greater than the geographical one." ${ }^{37}$ Though we might expect that the demands of life on board a vessel would sustain an impression of uniformity among the sailors, van der Post's narrative echoes those of mariners and passengers at other times in that he sees the ocean as providing opportunities in what historian John Mack has dubbed an "arena of transnational interchange." 38 The younger van der Post could not have known how significant his earliest encounters with the Japanese would be in helping him throw off the polarizing ideologies of wartime, but his older self was certainly aware of the benefits and sought to convey them to his readers. These have less to do with, say, appreciating shakuhachi music, Japanese calligraphy, or martial arts, than simply acknowledging the diversity of personalities aboard a ship that van der Post described as "a microcosm of the macrocosm of Japan, a sort of Bonsai tree of the spirit transplanted into this miniature pot of its culture afloat on a foreign sea." ${ }^{39}$ Within this "pot," the Captain, the purser, and the Chief Engineer are each the subject of distinct characterizations. ${ }^{40}$

The nature of these characterizations is certainly engaging, but each matters a good deal less than the simple fact of their existence and the diversity they bring to van der Post's writing, which served to differentiate the text from prior literature of the Asia-Pacific War, whether of the combat or the prisoner experience (stories relating to the latter underwent something of a revival in the period 1980-1995). ${ }^{41}$ Acclaimed literary fictions such as Norman Mailer's The Naked and the Dead (1948), Nevil Shute's A Town Like Alice (1950), Leon Uris' Battle Cry (1953), and James Jones' The Thin Red Line (1962) had done a great deal to complicate views of the Allied military and civilian experience during the war

\footnotetext{
${ }^{36}$ Paul Fussell has shown how contagious the travel phenomenon became: "This diaspora seems one of the signals of literary modernism, as we can infer from virtually no modern writer's remaining where he's 'supposed' to be except perhaps Proust - we think of Pound in London, Paris, and Italy; Eliot in London; Joyce in Trieste and Paris; Mann ultimately in the United States. The post-war flight from the Middle West of Hemingway, Fitzgerald, and Sinclair Lewis is the American counterpart of these European flights from a real or fancied narrowing of horizons." See Fussell, Abroad, 11.

${ }^{37}$ Fuller, "Inspirations at Sea Transcend the Rancor of War."

${ }^{38}$ Mack, The Sea, 21.

${ }^{39}$ van der Post, Yet Being Someone Other, 123.

${ }^{40}$ Ibid., 127-8.

${ }^{41}$ Bourke, Prisoners of the Japanese, 20-1.
} 
years, but they had not progressed very far when it came to humanizing the enemy. Part of the reason was innate to the experiences themselves: the battlefield or POW camp involved situations of social and spatial confinement, and to that extent had something in common with being on board a ship, but the antagonism between the respective groups meant that sociocultural boundaries tended to become steadily more entrenched rather than broken down. ${ }^{42}$ Moreover, these literary ventures paid heed, however implicitly, to the ideologies of racialization that had been prevalent during the war years themselves. An early study by historian Christopher Thorne reminds us of the differences in "perspective" that had held true at the time:

In contrast to the treatment of Germany and Italy (in which Hitler and Mussolini tended to be the main targets), written propaganda, films and cartoons in the USA and Canada attacked the entire Japanese people, and not their Emperor or Prime Minister alone, as being the embodiment of evil. "A Jap is a Jap," as General De Witt, in command of the Western United States military zone put it in 1943 with reference to American citizens of Japanese descent. ${ }^{43}$

In contradistinction to this discourse, van der Post's writing showed that Japanese were not a "Jap" but rather human beings whose interests and personalities, though often alien to one's own, would not stand in the way of friendship. In fact, where friendships were concerned, that which developed between Plomer and Captain Mori was so intimate that van der Post felt ostracized and responded by pairing off with the ship's purser who proceeded to teach him some rudimentary Japanese. ${ }^{44}$ That van der Post revisited these associations almost four decades after hostilities had ended made them not less, but rather more pertinent, especially in view of the revival of interest in-and writing of-literature about the Asia-Pacific War.

Whereas former combat servicemen in the USA were dusting off their war stories at this time, the moments that van der Post recalled, and the purposes he had in mind, involved more in the way of self-criticism than the irate jibes emerging on the other side of the Atlantic. As a cogent juxtaposition to Manchester's encounters with Japanese tourists, one might cite the author's description of the lifestyle enjoyed by moneyed Europeans in the Singapore of 1926:

We paid a ritual call, almost as if out of a certain politese d'histoire, on Raffles Hotel and were dismayed and fearful for the future from what we saw there of self-indulgence, excess of prosperity as well as fat on the Europeans of all races who congregated there. Appalled, we watched them, laughing and drinking there at high noon, in a dangerous measure, on cool verandahs and in darkened halls, humming with blades of whirling fans that were part of their highly organised systems of excluding the steaming world without seasons and the all-powerful sun which surrounded them. ${ }^{45}$

\footnotetext{
${ }^{42}$ Porter, Military Orientalism, 5.

${ }^{43}$ Thorne, "Racial Aspects of the Far Eastern War of 1941-1945," 350.

${ }^{44}$ van der Post, Yet Being Someone Other, 127-8.

${ }^{45}$ Ibid., 169.
} 
The Japanese tourists of Manchester's memoir had shown no awareness of the importance of the war years. Here, though, European expatriates are seen to be unaware of the war that is to come. Of course, the latter could not have known of the military disaster that awaited their brethren in February 1942, but van der Post, writing with a stylized determinism, strives to make his readers feel that they should have known, in a moral if not an historical sense. The judgment that he passes succeeds as an intervention against the ethnicization or nationalization of tourist behavior in exclusive terms, which, in turn, might make one wonder whether Manchester is the one with the short-term memory. Once one shrugs off the moral pontificating, there is really little difference between the two narratives, but, again, one must not assume that van der Post was specifically writing against the anti-tourist discourse of the 1980s, any more than he was writing in response to the corporate thriller genre. Rather, the point to draw here is that the prevalence of antagonistic sentiments toward the Japanese was not universal throughout the Anglophone world and that, whether coincidentally or purposefully, the particulars of South Africa's relationship with Japan during this period allowed for a literary perspective that was markedly divergent from those in the USA.

\section{Conclusion}

I began this article with a brief consideration of the ways in which Laurens van der Post distanced himself from longstanding cultural trends that objectify East Asian ethnic nationals, Jack London's “The Unparalleled Invasion" being an example of the type. Another writer who has written against this trend is the African American satirist Ishmael Reed, whose novel Japanese by Spring (1993) is, to the best of my knowledge, the only other literary source in which Japanophobia and South African themes intersect. Reed's narrative examines what takes place when "Jack London College" is purchased by Japanese investors, who turn it into "Tojo no Daigaku" (named after Japan's wartime Prime Minister) and instigate a brutal clampdown on campus politics, including those associated with the pro-apartheid "Amerikaner" student society. Reed draws upon fears of a Japanese "takeover" partly in order to construct a scenario in which South African politics are recontextualized, and yet the potential for sustained commentary goes unrealized, Reed being content to reduce the Amerikaners to fringe characters at the margins of the larger story of Japan-US trade relations. In the absence of additional American source material, therefore, the possibility for sustained comparisons between South African and American literary texts remains too slight and thus I have concentrated this article primarily on the writings of van der Post in order to expose how Japanophobia played out in a South African literary context. The 1926 voyage to Japan is of paramount importance here and may be "extracted" from the autobiography as a whole, partly because it comprises a standalone episode in its own right but also because much of the rest of the author's life story has been called into question by his biographer (William Plomer's account of the voyage 
acts to corroborate van der Post's, and is a topic that I address elsewhere) ${ }^{46}$ Van der Post clearly considered the interwar voyage a worthwhile topic even had the time not been ripe for examples of friendship between the members of formerly belligerent powers, which it surely was. Book reviewers were quick to note the author's commitment to reconciliation and one Briton wryly quipped that van der Post might have to be summoned for help in resolving trade tensions between the EEC and Japan. ${ }^{47}$ In Japan, van der Post's perspectives have garnered some appreciative commentary also. Shigemi Inaga has paid close attention to the role of hymns and folk songs in van der Post's work, and notes that when van der Post visited Japan in 1980, the hymn "Abide with Me" was sung by the Japanese who welcomed him. ${ }^{48}$ If one follows the lead of J.D.F. Jones, van der Post's biographer, one might wonder whether such an event actually took place. But I would suggest that answering this question is less important than the fact that a Japanese literature scholar should have identified a conciliatory tone largely absent in other Anglophone cultural texts. ${ }^{49}$

As for South Africa, that the literary culture of this nation did not manifest Japanophobia is no argument for greater racial tolerance within South African society at large. Simply speaking, South Africa was not tested in the way that American and Australasian societies were, because the economic situation of the day brought Japan and South Africa together in a state of unusual co-dependency. Technically, this was not the first time that such had taken place. During World War I, Germany had completely cut off its exports to South Africa, and Japan, which already had a trade relationship with South Africa, partially filled the void by increasing its own exports. ${ }^{50}$ But the 1980 s were different because Japan, always an object of some suspicion in any case, was vilified by American commentators in terms that made it appear as though the war of 1941-1945 had returned, albeit on a different plain. In an advisory statement that opens the introduction to the essay collection Perilous Memories (2000), readers are reminded that war memories are stimulated by present-day events: "National memories of war are neither static nor bounded but are connected in complex ways with transnational and global forces of all kinds." 51 The "South African" memory of the Pacific War was a fleeting one, having mainly to do with the seizure of French Madagascar in order

\footnotetext{
${ }^{46}$ J.D.F. Jones, van der Post's biographer, has suggested that today's readers approach Yet Being Someone Other "as a work of fiction, or, better, a romance." However, van der Post's daughter has stated that "We didn't treat what he said the way we treated the words of other men. It was a given that he was talking a 'poetic truth' and not a literal one." See Jones, Storyteller, 356; Lucia van der Post, "My Father, the Storyteller." For a close reading of William Plomer's writings on Japan, see my forthcoming article in positions: east asia cultures critique.

${ }^{47}$ Booker, "The Secrets of the Sea."; Delius, "Someone Other."

${ }^{48}$ Inaga, "Mediators, Sacrifice, and Forgiveness," 138.

${ }^{49}$ If one examines the representation of Japanese in contemporary American popular culture, one finds that Japan continues to signify a technological progress that exceeds that of the United States. The idea of robots as being analogous to Japanese workers also recurs. See Dobson, "Mister Sparkle meets the Yakuza," 53-4.

${ }^{50}$ Osada, op. cit., 35.

51"Introduction," Perilous Memories: The Asia-Pacific War(s), 8.
} 
to preempt the possibility of a Japanese invasion. ${ }^{52}$ Thus, the outrage occasioned by the behavior of Japanese tourists at battlefield sites would have resonated rather less in that country, but there are otherwise few grounds for assuming that South African literary productions would not have echoed American sentiments had the trade relationship with Japan not been so cozy.

\section{ACKNOWLEDGMENTS}

My thanks to the National Research Foundation (South Africa) for funding this project, and to Professor David Medalie and Pretoria University for hosting me during the academic year 2011-2012. I should also like to thank Roslyn Pachoca at the Library of Congress for providing copies of book reviews.

\section{REFERENCES}

Barthes, Roland. Empire of Signs. Trans. Richard Howard. London: Jonathan Cape, 1982. Originally published as L'empire des Signes (Genève: Albert Skira, 1970).

Bevilacqua, A.C. "With the Old Breed: At Peleliu and Okinawa." Marine Corps Gazette (pre-1994) 65, no. 12 (1981): 56-7.

Booker, Christopher. "The Secrets of the Sea". The Times, October 21, 1982.

Bourke, Roger. Prisoners of the Japanese: Literary Imagination and the Prisoner-of-War Experience. St. Lucia: University of Queensland Press, 2006.

Cumings, Bruce. "Rimspeak; or, the Discourse of the 'Pacific Rim'." In What Is in a Rim?: Critical Perspectives on the Pacific Region Idea, ed. Arif Dirlik, 53-72. Lanham: Rowman and Littlefield, 1998.

Delius, Anthony. "Someone Other". The Guardian, November 11, 1982.

Dobson, Hugo. "Mister Sparkle Meets the Yakuza: Depictions of Japan in The Simpsons." The Journal of Popular Culture 39, no. 1 (2006): 44-68.

Frank, Dana. "Demons in the Parking Lot: Auto Workers, Buy American Campaigns, and the 'Japanese Threat' in the 1980s." Amerasia Journal 28, no. 3 (2002): 33-50.

Fujitani, Takashi, Geoffrey M. White, and Lisa Yoneyama. "Introduction." In Perilous Memories: The Asia-Pacific War(s), ed. T.T. Fujitani, Geoffrey M. White, and Lisa Yoneyama, 1-29. Durham: Duke University Press Books, 2000.

Fuller, Edmund. "Inspirations at Sea Transcend the Rancor of War". Wall Street Journal, April 11, 1983.

Fussell, Paul. Abroad: British Literary Traveling between the Wars. New York: Oxford University Press, 1980.

Goodheart, Eugene. The Cult of the Ego: The Self in Modern Literature. Chicago, IL: The University of Chicago Press, 1968.

Hanasaki, Kohei. "Decolonization and the Assumption of War Responsibility." Trans. Ichiyo Muto. Inter-Asia Cultural Studies 1, no. 1 (2000): 71-83.

Inaga, Shigemi. "Mediators, Sacrifice, and Forgiveness: Laurens van der Post's Vision of Japan in the P.O.W. Camp in Reference to Takeyama Michio and the Ghost Plays of the Noh Theater." Japan Review 13 (2001): 129-43.

Jones, J.D.F. Storyteller: The Many Lives of Laurens Van Der Post. London: John Murray, 2001. Kamei, Shunsuke. "The Harbingers of Japanese-American Cultural Relations." Kanagawa Community News 15, no. 3 (1968): 20-4.

\footnotetext{
${ }^{52}$ For a summary of the campaign, see Wessels, "South Africa and the War against Japan 1941-1945."
} 
Lewis, Martin W., and Kären Wigen. The Myth of Continents: A Critique of Metageography. Berkeley: University of California Press, 1997.

London, Jack. The Unparalleled Invasion (308-16). McClure's Magazine, July, 1910.

Mack, John. The Sea: A Cultural History. London: Reaktion Books, 2011.

Manchester, William. Goodbye, Darkness: A Memoir of the Pacific War. London: Michael Joseph, 1981.

McKevitt, Andrew C. "Consuming Japan: Cultural Relations and the Globalizing of America, 1973-1993.” PhD diss., Temple University, 2009.

Michener, James A. “Guadalcanal.” In Return to Paradise, ed. James A. Michener, 124-36. Harmondsworth: Penguin, 1951.

Minear, Richard H. "Orientalism and the Study of Japan." In Edward Said, ed. Patrick Williams, Vol. 1, 337-49. London: Sage, 2001.

Noble, Gregory W. “Takeover or Makeover? Japanese Investment in America." California Management Review 34, no. 4 (1992): 127-47.

Osada, Masako. Sanctions and Honorary Whites: Diplomatic Policies and Economic Realities in Relations between Japan and South Africa. Contributions to the Study of World History. Westport: Greenwood Press, 2002.

Plomer, William. Paper Houses. London: Hogarth Press, 1929.

- The Autobiography of William Plomer. London: The Trinity Press, 1975.

Porter, Patrick. Military Orientalism: Eastern War through Western Eyes. Critical War Studies Series. Ed. Tarak Barkawi and Shane Brighton. London: C. Hurst, 2009.

Robins, Kevin, and David Morley. "Japan Panic". Marxism Today, 1991, 32-5.

Salter, James. The Hunters. New York: Vintage, 1999.

Schlossstein, Steven. Kensei. London: Arrow Books, 1985.

Shibusawa, Naoko. America's Geisha Ally: Reimagining the Japanese Enemy. Cambridge, MA: Harvard University Press, 2006.

Suvin, Darko. "The Soul and the Sense: Meditations on Roland Barthes on Japan." Canadian Review of Comparative Literature 18, no. 4 (1991): 499-531.

Tanner, Ron. "Toy Robots in America, 1955-1975: How Japan Really Won the War." The Journal of Popular Culture 28, no. 3 (1994): 125-54.

Tatsumi, Takayuki. Full Metal Apache: Transactions Between Cyberpunk Japan and Avant-Pop America. Post-Contemporary Interventions. Durham, NC: Duke University Press, 2006.

Thorne, Christopher. "Racial Aspects of the Far Eastern War of 1941-1945." Proceedings of the British Academy LXVI (1980): 329-77.

Tuan, Mia. Forever Foreigners or Honorary Whites?: The Asian Ethnic Experience Today. New Brunswick: Rutgers University Press, 1998.

van der Post, Laurens. Jung and the Story of Our Time. New York: Vintage Books, 1977.

Interview by Sandra Herrington. Tekweni TV Productions/SATV Channel, April 1992.

- Yet Being Someone Other. London: Vintage Classics, 2002.

van der Post, Lucia. "My Father, the Storyteller". Sunday Times Lifestyle, November 18, 2001.

Ward, Kerry. "'Tavern of the Seas?' The Cape of Good Hope as an Oceanic Crossroads During the Seventeenth and Eighteenth Centuries." In Seascapes: Maritime Histories, Littoral Cultures, and Transoceanic Exchanges, ed. Jerry H. Bentley, Renate Bridenthal, and Kären Wigen, 137-52. Honolulu: University of Hawai'i Press, 2007.

Wessels, André. "South Africa and the War against Japan 1941-1945." Military History Journal 10, no. 3 (1996), http://www.samilitaryhistory.org/vol103aw.html (accessed July 1, 2013).

Wilmsen, Edwin N. "Primal Anxiety, Sanctified Landscapes: The Imagery of Primitiveness in the Ethnographic Fictions of Laurens Van Der Post." Visual Anthropology 15, no. 2 (2002): 143-201.

Woolf, James B. "A Grand Tour: South Africa and American Tourists Between the Wars." The Journal of Popular Culture 25, no. 2 (1991): 99-116. 